\title{
UPAYA GURU MENINGKATKAN SIKAP SOSIAL SISWA MELALUI METODE DISKUSI PADA MATA PELAJARAN IPS
}

\author{
Binti Septiani ${ }^{1}$, Muhammad Widda Djuhan ${ }^{2}$ \\ ${ }^{1}$ Institut Agama Islam Negeri Ponorogo \\ septianibinti16@gmail.com \\ ${ }^{2}$ Institut Agama Islam Negeri Ponorogo \\ widdhadjuhan99@gmail.com \\ ABSTRAK
}

\begin{abstract}
Dalam proses belajar mengajar di sekolah tidak terlepas dari adanya proses interaksi sosial yang merupakan syarat utama terjadinya kegiatan sosial dilingkungan sekolah. Kegiatan belajar mengajar yang berkaitan dengan interaksi sosial salah satunya yaitu berdiskusi. Sikap sosial merupakan suatu tindakan seseorang untuk hidup dalam masyarakatnya seperti saling berinteraksi, saling membantu, saling menghargai, dan sebagainya. Sikap sosial perlu dikembangkan karena dapat menciptakan suasana hidup yang damai, rukun, nyaman, dan tentram. Pada saat membahas pelajaran Ilmu Pengetahuan Sosial metode diskusi sebagai penunjang berjalannya interaksi sosial dengan menunjukkan sikap sosial yang dimiliki masing-masing siswa. Ditemukan di SMP Negeri 1 Balong sesuai dengan hasil pengamatan dan wawancara peneliti, siswa kelas VIII $\mathrm{F}$ dalam kondisi pembelajaran, tampak bahwa sikap sosial siswa dikatagorikan kurang baik. Seperti yang peneliti temukan bahwa siswa tidak mencerminkan sikap jujur, sopan santun, dan kurangnya kerjasama. Sebagai contoh yang pertama, penyimpangan sikap jujur ditandai adanya ketika guru memberikan soal-soal ulangan atau tugas kemudian dikerjakan secara individu, hasilnya ada beberapa anak memiliki kemampuan kognitif yang kurang baik dan sebaliknya. Kecenderungan anak yang kognitifnya rendah melakukan tindakan yang kurang jujur karena lebih cenderung menggantungkan kepada siswa yang lebih pintar.
\end{abstract}

Kata kunci: sikap sosial, metode diskusi

\section{ABSTRACT}

In the teaching and learning process in schools it cannot be separated from the interaction process social, which is the main condition for the occurrence of social activities in the school environment. Activities teaching and learning related to social interaction, one of which is discussion. Attitude social is an act of someone to live in society like each other interact, help each other, respect each other, and so on. Social attitude is necessary developed because it can create a peaceful, harmonious, comfortable, and peaceful life atmosphere. When discussing Social Sciences lessons, the discussion method supports the course of social interaction by showing the social attitudes of each student. It was found at SMP Negeri 1 Balong according to the results of observations and interviews researcher, students of class VIII F in learning conditions, it appears that the students' social attitudes categorized as less good. As researchers found that students do not reflect honest attitude, courtesy, and lack of cooperation. As a first example, deviation of honest attitude is indicated when the teacher gives test questions or assignments then done individually, the result is that some children have cognitive abilities the less good and vice versa. The tendency of children with low cognitive 


\section{Upaya Guru Meningkatkan Sikap Sosial Siswa Melalui Metode Diskusi Pada Mata \\ Pelajaran IPS}

performance actions that are less honest because they tend to rely more on students smart.

Keywords: social attitude, discussion method

\section{PENDAHULUAN}

\section{A. Latar Belakang}

Sikap adalah kesadaran individu yang menentukan perbuatan nyata dan perbuatan-perbuatan yang mungkin akan terjadi dalam kegiatan-kegiatan sosial. Sikap sosial sangat dibutuhkan untuk menjalin hubungan dengan orang lain dalam kehidupan sehari-hari. Sikap sosial merupakan suatu tindakan seseorang untuk hidup dalam masyarakatnya seperti saling berinteraksi, saling membantu, saling menghargai, dan sebagainya. Sikap sosial perlu dikembangkan karena dapat menciptakan suasana hidup yang damai, rukun, nyaman, dan tentram. Sikap sosial merupakan tidakan yang dapat mengatasi berbagai masalah ada dalam masyarakat dengan berfikir secara bersama-sama.

Sikap sosial dalam kenyataanya yang tercerminkan pada siswa dipengaruhi oleh lingkungan sosialnya lingkungan tersebut berupa keluarga, sekolah dan masyarakat. Jika perkembangan anak difasilitasi secara baik dan benar maka siswa mencapai perkembangan sikap sosial yang baik. ${ }^{1}$ Apabila lingkungan sosial memfasilitasi siswa dengan dampak negatif maka sikap sikap sosial siswa akan dicerminkan perilaku yang buruk atau menyimpang. Oleh karena itu pengembangan sikap sosial siswa disekolah sangat penting dilakukan untuk perkembangan sikap sosial yang baik. Menurut kurikulum 2013 aspek sosial dibagi beberapa sikap yaitu: jujur, disiplin, tanggung jawab, sopan santun, peduli dan percaya diri.

Seperti halnya dilingkungan sekolah dapat mempegaruhi sikap dan perilaku siswa itu sendiri yang berdampak terhadap kelangsungan pembelajaran dikelas, bisa juga didalam sekolah, ataupun diluar sekolah. Di SMP Negeri 1 Balong sesuai dengan hasil pengamatan peneliti, siswa kelas VIII F dalam kondisi pembelajaran, tampak bahwa sikap sosial siswa dikatagorikan kurang baik. Seperti yang peneliti temukan bahwa siswa tidak mencerminkan sikap jujur, sopan santun, dan kurangnya kerjasama. Sebagai

\footnotetext{
${ }^{1}$ Danim Sudarwan, Perilaku Manusia (Jakarta: Perpusnas, 2004), 97.
} 
contoh yang pertama, penyimpangan sikap jujur ditandai adanya ketika guru memberikan soal-soal ulangan atau tugas kemudian dikerjakan secara individu, hasilnya ada beberapa anak memiliki kemampuan kognitif yang kurang baik dan sebaliknya. Kecenderungan anak yang kognitifnya rendah melakukan tindakan yang kurang jujur karena lebih cenderung bergantung kepada siswa yang lebih pintar. Kedua, Peneliti menemukan penyimpangan sikap sopan santun. Ditandai adanya siswa yang masih menggunakan bahasa yang kurang sopan kepada guru maupun teman sebayanya. Ketiga, peniliti menemukan penyimpangan sikap kerjasama. Ditandai masih adanya siswa yang tidak selesai mengerjakan tugas tepat pada waktunya.

Dari hasil observasi penelitian diatas peneliti menemukan pada salah satu guru mata pelajaran IPS kelas VIII F untuk mengatasi permasalahan tersebut menggunakan metode diskusi. Anak dalam perkembangannya dipengaruhi oleh orang tua atau wali (pendidikan informal), guru-guru (pendidikan formal), dan masyarakat (pendidikan nonformal). Keberhasilan pendidikan di sekolah bukan hanya ditentukan oleh usaha murid secara individual atau berkat interaksi murid dan guru dalam proses belajar mengajar, melainkan juga oleh interaksi anak atau siswa dengan lingkungan sosialnya dalam berbagai situasi yang dihadapi di dalam maupun di luar sekolah. Diskusi kelas merupakan interaksi antara siswa dan siswa atau siwa dengan guru untuk menganalisis, memecahkan masalah, menggali atau memperdebatkan permasalahan tertentu. Tetapi yang perlu dipahami, bahwa diskusi merupakan titik sentral dalam semua aspek pembelajaran, maka diskusi kelas merupakan pendekatan yang berbeda dalam suatu pembelajaran. Atas alasan demikian diskusi kelas merupakan salah bagian penting dalam suatu proses pembelajaran. Dengan kata lain, interaksi antara guru dengan siswa, siswa dengan siswa dalam proses pembelajaran sangat ditentukan oleh bagaimana proses diskusi kelas dapat dioptimalisasikan. ${ }^{2}$ Dengan diskusi kelas ini guru dapat mengubah beberapa pola komunikasi yang tidak bermanfaat menjadi bermanfaat atau berkualitas dengan sesuai pembahasan di kelas merupakan ciri kebanyakan kelas pada saat ini.

2 Trianto, Medesain Model Pembelajaran Inovatif-Progresif (Jakarta: Kencana Prenada Media Group, 2009), 121-122. 


\section{Upaya Guru Meningkatkan Sikap Sosial Siswa Melalui Metode Diskusi Pada Mata Pelajaran IPS}

Pembahasan mengenai sikap sosial pada khususnya tidak bisa dilepaskan kaitannya dengan mata pelajaraan Ilmu Pengetahuan Sosial (IPS). Ilmu Pengetahuan Sosial dalam pendidikan merupakan suatu konsep yang mengembangkan pengetahuan, sikap, dan keterampilan sosial dalam rangka membentuk dan mengembangkan pribadi warga negara yang baik, juga telah menjadi bagian dari wacana kurikulum dan sistem pendidikan di Indonesia, dan merupakan program pendidikan sosial pada jalur pendidikan sekolah. Pada dasarnya tujuan dari pendidikan IPS secara umum adalah untuk mendidik dan memberi bekal kemampuan dasar kepada siswa untuk mengembangkan diri sesuai dengan bakat, minat, kemampuan dan lingkungannya, serta berbagai bekal bagi siswa untuk melanjutkan pendidikan ke jenjang lebih tinggi. Nursid Gunawan menyatakan bahwa "tujuan pendidikan IPS adalah membina anak didik menjadi warga negara yang baik, yang memiliki pengetahuan, dan kepedulian sosial". Secara rinci Hamalik Gunawan, merumuskan tujuan pendidikan IPS adalah berorientasi pada tingkah laku para siswa, yaitu: (1) pengetahuan dan pemahaman, (2) sikap hidup belajar, (3) nilai-nilai sosial dan sikap, (4) keterampilan. Bila ditinjau dari ruang lingkup, objek dan tujuannya maka dapat dikatakan bahwa Ilmu Pengetahuan Sosial (IPS) adalah suatu mata pelajaran yang mempelajari, menelaah dan menganalisis gejala dan masalah sosial dalam masyarakat ditinjau dari berbagai aspek kehidupan secara terpadu. ${ }^{3}$

Jika ditinjau lebih mendalam lagi, maka nampak bahwa yang dibicarakan dalam IPS itu tak lain adalah hubungan antara manusia yang mencakup hubungan individu dengan kelompok, kelompok dengan kelompok, serta kelompok dengan alam lingkungannya. ${ }^{4}$ Terjalinnya hubungan yang baik dengan teman sebaya dalam berinteraksi merupakan salah satu hal yang dapat menunjang sikap sosial siswa dalam berperilaku. Permendikbud No.21 tahun 2016 tentang Standar Isi mendefinisikan sikap sosial sebagai suatu sikap yang menunjukan perilaku jujur, disiplin, santun, percaya diri, peduli, dan

${ }^{3}$ Edy Suharman, "Peran Guru IPS sebagai Pendidik dan Pengajar dalam Meningkatkan Sikap Sosial dan Tanggung Jawab Sosial Siswa SMP,"Harmoni Sosial: Jurnal Pendidikan IPS, 1 (Maret, 2017), 3.

${ }^{4}$ Abdul Kadir, Dasar-Dasar Pendidikan (Jakarta: Kencana Prenada Media Group, 2012), 157. 
bertanggung jawab dalam berinteraksi dengan keluarga, teman, guru, tetangga, dan Negara. ${ }^{5}$

Apapun pendapat orang tentang suatu sikap tertentu, yaitu sikap yang baik dan diharapkan oleh masyarakat untuk dimiliki para siswa dan para tamatan sekolah, diharapkan dapat terbentuk dan tertanam melalui pendidikan sekolah. Sikap dianggap hasil belajar yang sangat penting. Dengan menanamkan kebiasaan-kebiasaan tertentu melalui pengetahuan, pengertian, dan keterampilan diharapkan setahap demi setahap dapat ditanamkan juga sikap-sikap tertentu, yang akan sangat berguna bagi para siwa.

Dengan belajar mengajar melalui metode diskusi, maka diharapkan siswa dapat berinterasksi sosial dengan teman sebaya atau gurunya dengan baik dan berantusias megikuti kegiatan pelajaran dengan saksama. Selain itu dapat meningkatkan sikap sosial pada siswa saat melaksanakan kegiatan diskusi diharapkan siswa dapat menumbuhkan sikap menghargai, disiplin, santun, cinta damai, toleransi dan lain-lain.

Dari pemaparan di atas, peneliti tertarik untuk melakukan kegiatan pengamatan dan memahami perilaku siswa atau kelompok siswa dalam stuasi saat pembelajaran kegiatan diskusi berlangsung. Agar mengetahui tanggapan siswa-siswi saat berdiskusi di kelas yang dilihat dari segi cara berinteraksi dengan baik, dan menyikapi lawan diskusidengan baik. Maka dari itu peneliti langsung melakukan pengamatan di kelas VIII F. Tempat penelitian ini dilakukan di SMP Negeri 1 Balong Kabupaten Ponorogo. Peneliti memilih tempat ini karena dilihat dari gurunya yang memiliki jiwa sosial yang tinggi dan sangat mendukung untuk dijadikan tempat penelitian yang nantinya diharapkan akan mempermudah langkah peneliti baik saat mencari data dan mengumpulkan data.

Berangkat dari latar belakang tersebut, penulis tertarik untuk melakukan upaya penelitian melalui permasalahan yang dihadapi siswa dengan judul “Upaya Guru Meningkatkan Sikap Sosial Siswa melalui Metode Diskusi pada

${ }^{5}$ Permendikbud Nomor 21 Tahun 2016 tentang Stadar Kompetensi Lulusan Pendidikan Dasar dan Menengah. 


\section{Upaya Guru Meningkatkan Sikap Sosial Siswa Melalui Metode Diskusi Pada Mata Pelajaran IPS}

Mata Pelajaran IPS untuk Siswa Kelas VIII F SMP Negeri 1 Balong Ponorogo".

\section{B. Tujuan Penelitian}

Berdasarkan rumusan masalah yang disebutkan maka tujuan penelitian yang ingin dicapai adalah:

1. Untuk mengetahui upaya guru dalam meningkatkan sikap jujur siswa melalui metode diskusi pada mata pelajaran IPS kelas VIII F SMP Negeri 1 Balong Ponorogo?

2. Untuk mengetahui upaya guru dalam meningkatkan sikap sopan satun siswa melalui metode diskusi pada pelajaran IPS kelas VIII F di SMP Negeri 1 Balong Ponorogo?

3. Untuk mengetahui upaya guru dalam menigkatkan sikap kerjasama siswa melalui metode diskusi pada pelajaran IPS kelas VIII F di SMP Negeri 1 Balong Ponorogo?

\section{METODE PENELITIAN}

Pendekatan penelitian yang digunakan dalam penelitian ini adalah pendekatan kualitatif. Sumber data utama dalam penelitian kualitatif ini adalah kata-kata dan tindakan selebihnya adalah data tambahan seperti dokumen dan lain-lain. ${ }^{6}$ Kata-kata dan tindakan orang-orang yang di amati atau di wawancarai merupakan sumber data utama. Teknik pengumpulan data pada penelitian ini meliputi wawancara, observasi dan dokumentasi. Sebab bagi peneliti kualitatif fenomena dapat dimengerti maknanya secara baik apabila dilakukan interaksi dengan subyek, melalui wawancara mendalam dan diobservasi pada latar, dimana fenomena tersebut berlangsung.

Berkaitan dengan hal tersebut, maka sumber data dalam penelitian ini disesuaikan dengan fokus dan tujuan penelitian. Sehingga yang dijadikan sumber data adalah sebagai berikut:

1. Informan yang meliputi guru mata pelajaran IPS dan siswa-siswi kelas VIII di SMP Negei 1 Balong Ponorogo. 
2. Dokumen data SMP Negeri 1 Balong yang meliputi gambaran umum saat KBM melalui metode diskusi dan dokumen-dokumen lainnya seperti foto, catatan tertulis dan bahan-bahan lain yang berkaitan dengan penelitian.

Sumber data utama dicatat melalui catatan tertulis atau melalui perekaman video, pengambilan foto atau film. Sumber tertulis dapat berupa sumber dari arsip, dokumen pribadi maupun dokumen resmi. Foto menghasilkan data deskriptif yang cukup berharga dan sering di gunakan untuk menelaah segi-segi subjektif dan hasilnya sering di analisis secara induktif.

Teknik analisis data adalah proses mengatur urutan data, mengorganisasikannya kedalam suatu pola, kategori, dan satu uraian dasar. ${ }^{7}$ Menurut Miles dan Huberman, analisis data kualitatif adalah susatu proses analisis yang terdiri dari tiga alur kegiatan yang terjadi secara bersamaan, yaitu Reduksi Data(Reduction Data), Penyajian Data (Data Display), dan Penarikan Kesimpulan(Verification). ${ }^{8}$ Kegiatan analisis dilakukan dengan menelaah data, menata, membagi menjadi satuan-satuan yang dapat dikelola, mensistensis, mencari pola, menemukan apa yang bermakna dan apa yang akan diteliti dan dilaporkan secara sistematis, yakni data kegiatan yang dilakukan oleh Guru Ilmu Pengetahuan Sosial SMP Negeri 1 Balong. Adapun langkah-langkah dari analisis data adalah sebagai berikut:

\section{a. Data Reduksi (Reduction Data)}

Reduksi data diartikan sebagai proses pemilihan, pemutusan perhatian pada penyederhanaan, dan transformasi data kasar yang muncul dari catatancatatan tetulis di lapangan. Mereduksi data dalam konteks penelitian yang dimaksud adalah merangkum, memilih hal-hal yang pokok, memfokuskan pada hal-hal yang penting, membuat kategori dan pemusatan perhatian. Dengan demikian data yang telah direduksikan memberikan gambaran yang lebih jelas dan mempermudah peneliti untuk melakukan pengumpulandata selanjutnya, proses ini berlangsung selama penelitian ini dilakukan dari awal sampai akhir penelitian. ${ }^{9}$ Dengan reduksi data penelti tidak perlu

7 Basrowi dan Suwandi, Memahami Penelitian Kualitataif (Jakarta: PT Rineka Cipta, 2008), 94.

8 Andi Prastowo, Metode Penelitian Kualitatif Dalam Prespektif Rancangan Penelitian (Yogyakarta: AR-Ruzz Media, 2014), 241.

${ }^{9}$ Emir, Metodologi Penelitian Kualitatif Analisis Data (Jakarta: Rajawali Press, 2011), 


\section{Upaya Guru Meningkatkan Sikap Sosial Siswa Melalui Metode Diskusi Pada Mata Pelajaran IPS}

mengartikannya sebagai kuantifikasi. Data kualitatif dapat disederhanakan dan ditransformasikan dalam dalam aneka macam cara, yakni: melalui seleksi yang ketat, melalui ringkasan atau uraian singkat, menggolongkannya dalam satu pola yang lebih luas, dan sebagainya.

b. Penyajian Data (Data Display)

Miles dan Huberman membatasi suatu penyajian sebagai sekumpulan informasi tersusun yang memberi kemungkinan adanya penarikan kesimpulan dan pengambilan tindakan. ${ }^{10}$ Setelah data direduksi, maka langkah selanjutnya adalah mendisplaykan data ataumenyajikan data kedalampolayang dilakukan dalam berupa teks naratif, bagan, grafik, metrik, dan jaringan. Dengan proses ini peneliti mengelompokkan hal-hal yang serupa menjadi kategori dan kelompok-kelompok. Kemudian melakukan displaydata secara sistematik agar lebih mudah dipahami interaksiantara bagian-bagiannya.Dalam proses ini data diklasifikasikan berdasarkan tema-tema. ${ }^{11}$

c. Penarikan Kesimpulan (Verification)

Langkah ketiga dalam teknik analisis data kualitatif adalah penarikan kesimpulan dan verifikasi. Penarikan kesimpulan hanyalah sebagian dari satu kegiatan dari konfigurasi yang utuh. Kesimpulan-kesimpulan juga diverifikasi selama penelitian berlangsung. Verifikasi itu mungkin sesingkat pemikiran kembali yang melintas dalam pikiran penganalisis selamaia menulis suatu tinjauan ulang pada catatan lapangan. ${ }^{12}$ Kesimpulan awal yang dikemukakan masih berifat sementara, akanberubah jika tidak ditemukan bukti-bukti yang kuat dan yang mendukung pada tahapan pengumpulan data berikutnya tetapi apabila kesimpulan pada tahap awal sudah didukung oleh bukti-bukti yang valid dan konsisten saat peneliti kembali kelapangan mengumpulkan data, maka kesimpulan yang dikemukakan merupakan kesimpulan yang kredibel. Kesimpulan dalam penelitian kualitatif adalah merupakan temuan baru yang atau belum pernah ada. ${ }^{13}$

${ }^{10}$ Milles dan Huberman, Analisis Data Kualitatif, (Jakarta: Universitas Indonesia Press, 1992), 16.

${ }^{11}$ Sugiyono, Metodologi Penelitian Kualitatif dan R\&D (Bandung: Alfabeta, 2007), 341.

12 Ariesto Hadi Sutopo dan Andrianus Arif, Terampil Mengolah Data Kualitatif DenganNVIVO (Jakarta: Kencana Pranada Media Group, 2010), 11.

${ }^{13}$ Ibid, 345. 
Pada langkah terakhir analisis yaitu penarikan kesimpulan atau verifikasi ini di harapkan peneliti mendapat temuan baru yang sebelumnya belum pernah ada. Temuan dapat berupa diskrips iatau gambaran suatu objek yang sebelumnya masih remang-remang atau gelap sehingga setelah diteliti akan menjadi jelas.

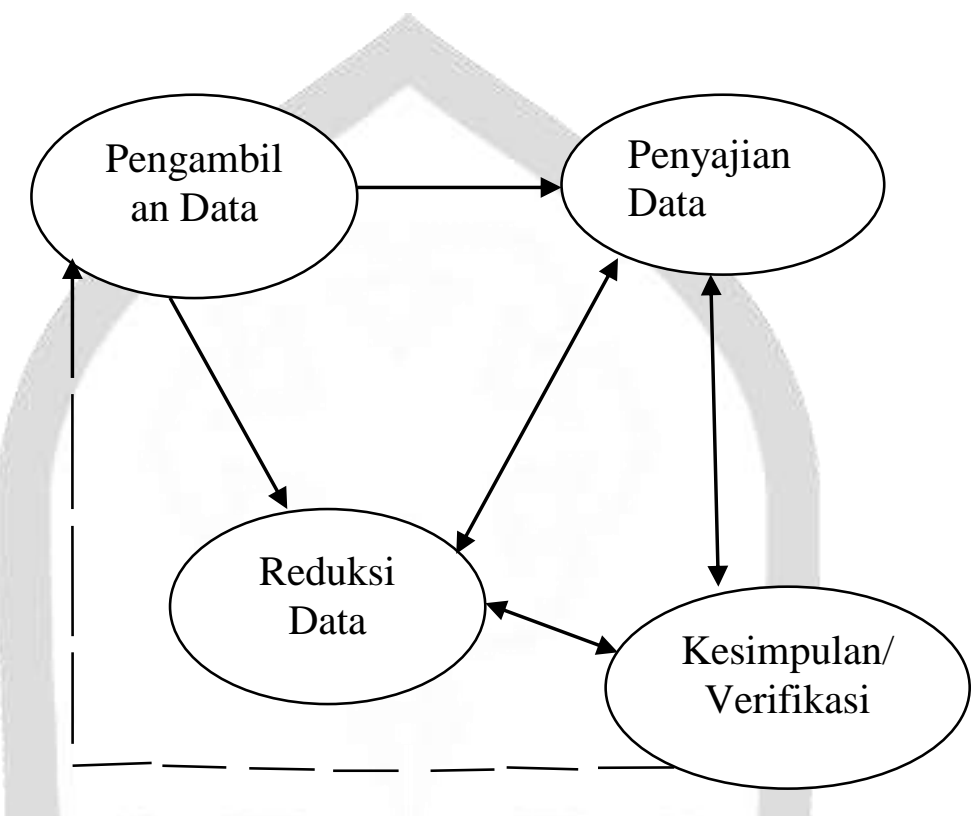

Gambar 1.1 Teknik Analisis Data menurut Miles dan Huberman

\section{HASIL DAN PEMBAHASAN}

Menurut Ahmad sikap sosial dinyatakan tidak seseorang saja tetapi diperhatikan oleh orang-orang sekelompoknya, objeknya adalah objek sosial (objek banyak orang dalam kelompok) dan dinyatakan berulang-ulang. Seorang individu sangat erat hubunganya dengan sikapnya masing-masing sebagai ciri pribadinya. Sikap pada umumnya sering diartikan sebagai suatu tindakan yang dilakukan individu untuk memberikan tanggapan pada suatu hal. Pengertian sikap dijelaskan oleh Saifudin Azwar sikap diartikan sebagai suatu reaksi atau respon yang muncul dari seseorang individu terhadap objek yang kemudian memunculkan perilaku individu terhadap objek tersebut dengan cara-cara tertentu.

Penilaian sikap dilakukan berdasarkan KI-2, yang kemudian dikembangkan untuk menentukan indikator dari KI sebagaiberikut:

Tabel 1.1 Contoh Pengembangan Indikator KI-2 


\section{Upaya Guru Meningkatkan Sikap Sosial Siswa Melalui Metode Diskusi Pada Mata Pelajaran IPS}

\begin{tabular}{|c|c|}
\hline $\begin{array}{l}\text { 1. Jujur adalah perilaku } \\
\text { dapat dipercaya dalam } \\
\text { perkataan, tindakan, dan } \\
\text { perbuatan } \\
\text { pekerjaan. }\end{array}$ & $\begin{array}{l}\text { a. Tidak menyontek dalam mengerjakan ujian atau } \\
\text { ulangan } \\
\text { b. Tidak menjadi plagiat (mengambil atau menyalin } \\
\text { karya orang lain tanpa menyebutkan sumber) } \\
\text { c. Mengungkapkan perasaan apa adanya } \\
\text { d. Menyerahkan kepada yang berwenang barang yang } \\
\text { ditemukan } \\
\text { e. Membuat laporan berdasarkan data atau informasi } \\
\text { f. Mengakui kesalahan atau kekurangan yang dimiliki }\end{array}$ \\
\hline $\begin{array}{l}\text { 2. Disiplin adalah tindakan } \\
\text { yang menunjukkan } \\
\text { perilaku tertib dan patuh } \\
\text { pada berbagai ketentuan } \\
\text { dan peraturan. }\end{array}$ & $\begin{array}{l}\text { a. Datang tepat waktu } \\
\text { b. Patuh pada tata tertib atau aturan bersamasekolah } \\
\text { c. Mengerjakan atau mengumpulkan tugas sesuai } \\
\text { dengan waktu yang ditentukan } \\
\text { d. Mengikuti kaidah berbahasa tulis yang baik dan } \\
\text { benar }\end{array}$ \\
\hline 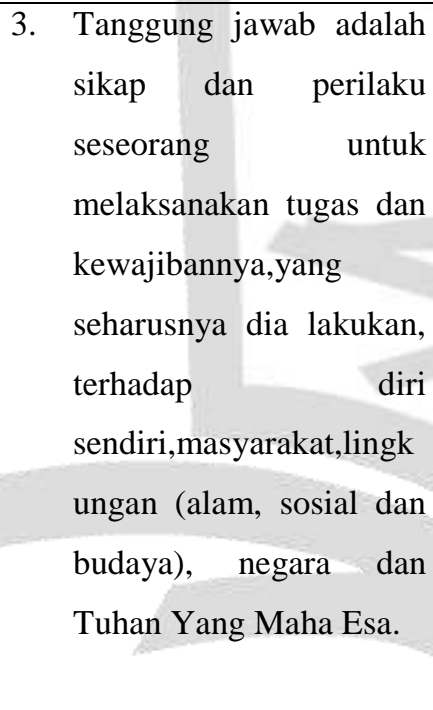 & $\begin{array}{l}\text { a. Melaksanakan tugas individu dengan baik } \\
\text { b. Menerima resiko dari tindakan yang dilakukan } \\
\text { c. Tidak menyalahkan atau menuduh orang lain tanpa } \\
\text { bukti yang akurat } \\
\text { d. Mengembalikan barang yang dipinjam } \\
\text { e. Mengakui dan meminta maaf atas kesalahan yang } \\
\text { dilakukan } \\
\text { f. Menepati janji } \\
\text { g. Tidak menyalahkan orang lain untuk kesalahan } \\
\text { h. Melaksanakan apa yang pernah dikatakan tanpa } \\
\text { disuruh/diminta }\end{array}$ \\
\hline $\begin{array}{l}\text { 4. Toleransi adalah sikap } \\
\text { dan tindakan yang } \\
\text { menghargai } \\
\text { keberagaman latar. }\end{array}$ & $\begin{array}{l}\text { a. Tidak mengganggu teman yang berbeda pendapat } \\
\text { b. Menerima kesepakatan meskipun berbeda dengan } \\
\text { pendapatnya } \\
\text { c. Dapat menerima kekurangan orang lain Sikap sosial } \\
\text { Indikator belakang, pandangan, dan keyakinan } \\
\text { d. Dapat mememaafkan kesalahan orang lain } \\
\text { e. Mampu dan mau bekerja sama dengan siapa pun } \\
\text { yang memiliki keberagaman latar belakang, } \\
\text { pandangan, dan keyakinan } \\
\text { f. Tidak memaksakan pendapat atau keyakinan diri } \\
\text { gada orang lain } \\
\text { g. Kesediaan untuk belajar dari (terbuka terhadap) }\end{array}$ \\
\hline
\end{tabular}


JIPSI: Jurnal Ilmiah Ilmu Pengetahuan Sosial Indonesia Nomor 1 Volume 1 Tahun 2021, hal 61-78

\begin{tabular}{|c|c|}
\hline & $\begin{array}{l}\text { keyakinan dan gagasan orang lain agar dapat } \\
\text { memahami orang lain lebih baik } \\
\text { h. Terbuka terhadap atau kesediaan untuk menerima } \\
\text { sesuatu yang baru }\end{array}$ \\
\hline $\begin{array}{l}\text { 5. Gotong-royong adalah } \\
\text { bekerja bersama-sama } \\
\text { dengan orang lain untuk } \\
\text { mencapai tujuan bersama } \\
\text { dengan saling berbagi } \\
\text { tugas dan tolong } \\
\text { menolong secara ikhlas. }\end{array}$ & $\begin{array}{l}\text { a. Terlibat aktif dalam bekerja bakti membersihkan } \\
\text { kelas atau sekolah } \\
\text { b. Kesediaan melakukan tugas sesuai kesepakatan } \\
\text { c. Bersedia membantu orang lain tanpa mengharap } \\
\text { imbalan } \\
\text { d. Aktif dalam kerja kelompok } \\
\text { e. Memusatkan perhatian pada tujuan kelompok } \\
\text { f. Tidak mendahulukan kepentingan pribadi } \\
\text { g. Mencari jalan untuk mengatasi perbedaan } \\
\text { pendapat/pikiran antara diri sendiri dengan orang } \\
\text { h. Mendorong orang lain untuk bekerja sama demi } \\
\text { mencapai tujuan bersama }\end{array}$ \\
\hline 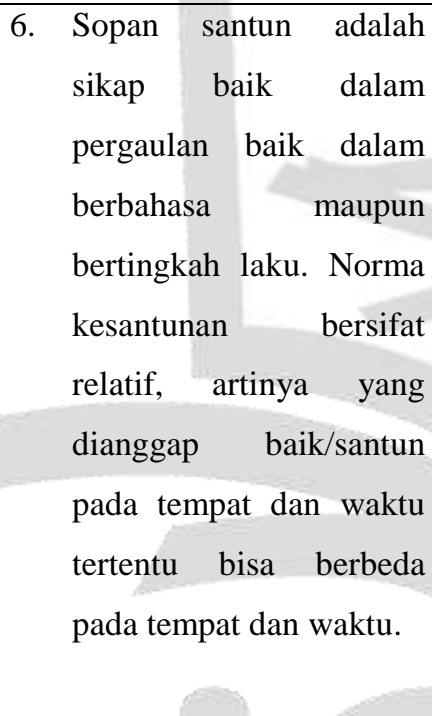 & $\begin{array}{l}\text { a. Menghormati orang yang lebih tua. } \\
\text { b. Tidak berkata-kata kotor, kasar, dan takabur. } \\
\text { c. Tidak meludah di sembarang tempat. } \\
\text { d. Tidak menyela pembicaraan pada waktu yang tidak } \\
\text { tepat } \\
\text { e. Mengucapkan terima kasih setelah menerima } \\
\text { bantuan orang lain } \\
\text { f. Bersikap 3S (salam, senyum, sapa) } \\
\text { g. Meminta ijin ketika akan memasuki ruangan orang } \\
\text { h. Memperlakukan orang lain sebagaimana diri sendiri } \\
\text { ingin diperlakukan }\end{array}$ \\
\hline 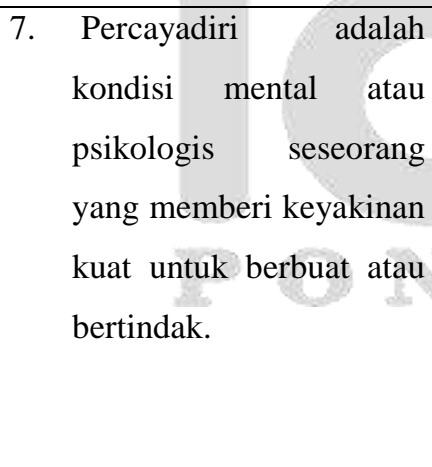 & $\begin{array}{l}\text { Berpendapat atau melakukan kegiatan tanpa ragu- } \\
\text { ragu. } \\
\text { Mampu membuat keputusan dengan cepat } \\
\text { Tidak mudah putus asa } \\
\text { Tidak canggung dalam bertindak } \\
\text { Berani presentasi di depan kelas } \\
\text { Berani berpendapat, bertanya, atau menjawab } \\
\text { pertanyaan. }\end{array}$ \\
\hline
\end{tabular}




\section{Upaya Guru Meningkatkan Sikap Sosial Siswa Melalui Metode Diskusi Pada Mata Pelajaran IPS}

Metode diskusi adalah suatu cara penyajian bahan pelajaran di mana guru memberi kesempatan kepada para siswa (kelompok-kelompok siswa) untuk mengadakan perbincangan ilmiah guna mengumpulkan pendapat, membuat kesimpulan, atau menyusun berbagai alternatif pemecahan atas suatu masalah.

\section{A. Analisis upaya guru dalam meningkatkan sikap jujur siswa melalui metode diskusi pada pelajaran IPS kelas VIII F SMP Negeri 1 Balong Ponorogo}

Jujur merupakan modal dasar dalam kehidupan bersama dan kunci keberhasilan. Melalui kejujuran kita dapat mempelajari, memahami, dan mengerti tentang keseimbangan-keharmonisan. Setelah peneliti melakukan wawancara dengan salah satu guru IPS kelas VIII F, menyampaikan bahwa selalu mengajarkan siswa-siswinya untuk selalu bersikap jujur. Berbagai masalah yang dihadapi oleh siswa-siswi di kelas VIII F mengenai sikap jujurnya dengan ini guru berupaya untuk meningkatkan sikap jujur pada murid.

Penerapan sikap jujur kehidupan kita itu sangat penting perlu dibutuhkan dalam kehidupan sehari-hari. Karena sikap jujur itu adalah sikap yang terpuji. Kejujuran adalah sangat penting bagi setiap orang dan kita harus terbiasa menanamkan itu dalam kehidupan sehari-hari. Karena setiap orang itu berbeda-beda mempunyai suatu perilaku dan tidak semua amanah bersifat umum dan terbuka. Fadillah mengatakan bahwa jujur merupakan perilaku yang patuh dalam perkataan, tindakan, dan pekerjaan. ${ }^{14}$

Berdasarkan hasil observasi yang dilakukan peneliti pada tanggal 28 Maret 2020, di kelas VIII F diperoleh informasi bahwa pembelajaran IPS di SMP Negeri 1 Balong Ponorogo sangat berperan dalam penanaman nilai karakter. Karakter yang dimaksud diantaranya kerjasama, sikap sopan santunnya, dan kejujuran. Dari nilai kejujuran sendiri disini dapat diimplementasikan nilai kejujuran dalam pembelajaran IPS dilakukan cara menerapkan pemberlajaran berbasis karakter di kelas sebagaimana dimuat dalam kurikulum 2013 melalui metode diskusi.

\footnotetext{
${ }^{14}$ Daviq Chairilsyah Metode dan Teknik Mengajarkan Kejujuran pada Anak Sejak Usia Dini (Riau:Educhild, 2016) 9.
} 
Darihasil wawancara dapat disimpulkan bahwa, sikap kejujuran itu merupakan kesesuaian sikap antara perkataan dan perbuatan. Kejujuran itu harus dimiliki setiap individu karena jujur membawa kebaikan untuk diri sendiri dan orang lain. Guru IPS ibu Siti Nurhayati, S. Pd. Selalu berpesan kepada siswa-siswinya agar selalu berkata atau berbuat jujur kapanpun dan dimanapun mereka berada. Karena kejujuran merupakan salah satu kunci dari kesuksesan.

Pembentukan sikap jujur yang di terapkan oleh guru IPS dengan melalui beberapa hal yaitu keteladanan, kegiatan spontan, kegiatan rutin, dan pengondisian. Yang dimaksudkan keteladanan disini yaitu perilaku atau sikap guru atau tenaga pendidik dalam memberikan contoh melalui tindakantindakan yang baik sehingga diharapkan menjadi panutan bagi siswa-siswinya. Sebagai contoh kecil sikap jujur guru terhadap siswanya yaitu guru memberikan penilaian secara objektif kepada seluruh siswa-siswinya. Kegiatan spontan merupakan kegiatan yang tidak terjadwal dalam kejadian khusus, meliputi pembentukan perilaku memberikan senyum, salam, sapa, mengatasi perbedaan pendapat dan lain sebagainya. Di SMP Negeri 1 Balong juga disediakan kantin kejujuran, dari kantin kejujuranlah dapat melatih siswasiswinya dapat membentuk sikap jujur. Pengkondisian merupakan menciptakan kondisi yang mendukung terlaksananya pendidikan karakter, misalnya memasang poster kata-kata bijak dilingkungan sekolah, menjadikan lingkungan sekolah yang bersih, nyaman, damai, dan aman.

Jika ada murid yang bertindak tidak jujur, maka Ibu Siti akan menegurnya, menasehatinya, dan memberikan sanksi. Contohnya jika ada murid yang ketahuan menyontek akan langsung beri tugas yang dapat didiskusikan dengan temannya agar anak itu benar-benar faham dengan materi yang kurang dimengerti agar dipertemuan berikutnya tidak terjadi lagi murid yang menyontek. Cara meningkatkan sikap kejujuran pada siswa-siswinya yaitu dimulai dari gurunya, seorang guru harus bisa menjadi teladan bagi siswanya. Jika seorang guru ingin membangun karakter jujur pada anak didiknya, maka karakter jujur itu harus terbiasa muncul dulu pada gurunya. Sikap jujur jika dikatkan dengan metode diskusi juga dapat melatih kejujuran siswa dengan melalui kegiatan diskusi kita dapat mengetahui kemampuan 


\section{Upaya Guru Meningkatkan Sikap Sosial Siswa Melalui Metode Diskusi Pada Mata Pelajaran IPS}

murid saat berfikir, saat menemukan solusi, aktif atau tidaknya saat berpendapat dan sebagainya. Karena sebagian besar murid yang berdiam diri saat diskusi itu, murid yang kurang menguasai materi. Sedangkan jika ditanya sudah faham apa belum jawabnya sudah, tetapi setelah diuji diberi sebuah pertanyaan belum bisa menjawab. Berarti dapat disimpulkan anak itu tidak jujur, jika dirinya belum faham. Biasanya yang menyebabkan siswa itu melakukan tindakan tidak jujur jika dilihat dari pengalaman dan pengamatan dilingkungan sekolah yaitu, siswa yang melakukan perilaku tidak jujur diantaranya yaitu karena takut mengakui kesalahannya.

B. Analisis upaya guru meningkatkan sikap sopan santun siswa pada pelajaran IPS Kelas VIII F di SMP Negeri 1 Balong Ponorogo

Sikap sopan santun yang sangat menjunjung tinggi nilai-nilai hormat menghormati sesama, yang muda menghormati yang tua, dan yang tua menghargai yang muda tidak lagi kelihatan dalam kehidupan serba modern ini. Hilangnya sikap sopan santun sebagian siswa sebagian siswa merupakan salah satudari sekian penyebab kurang terbentuknya karakter. Anak pun relatif mudah menyesuaikan diri dengan lingkungan baru, selalu menghargai orang lain, penuh percaya diri, dan memiliki kehidupan yang baik. Pendek kata dia tumbuh menjadi sosok yang beradab.

Sikap sopan santun siswa saat di kelas VIII F saat pembelajaran diskusi kelompok yaitu selama kegiatan diskusi berlangsung, ada siswa yang kurang memperhatikan, saat menyampaikan pendapat kurang sopan dengan bahasa yang baik, kurang menghargai satu sama lain. Akan tetapi juga ada beberapa siswa-siswi yang mengikuti kegiatan diskusi dengan baik, menghargai pendapat teman, tidak berbuat gaduh, selalu berbicara dengan baik. Cara menyikapi murid yang kurang sopan santun yaitu dengan menasehati, dan memberi contoh yang baik. Sebagai contoh saat kegiatan diskusi berlangsung dianjurkan tidak ada teman yang menyela pembicaraan teman lainnya.

Penyebab lunturnya sikap sopan santun pada siswa adalah biasanya dapat dilihat dari faktor internal dan eksternalnya. Misalnya. Kurangnya pembiasaan sopan santun di rumah, pergaulan bebas, sering berkata kasar, suka merintah, dan lain-lain. Cara mengetahui perilaku siswa saat di rumah yaitu, dengan adanya kontak sosial melelui media sosial, guru dan wali murid 
biasanya saling memberikan informasi mengenai sikap anak ketika di sekolahan dan di rumah. Murid yang tidak bisa menjaga sikap sopan santunnya biasanya dapat dilihat dari faktor internal dan eksternalnya. Misalnya. Kurangnya pembiasaan sopan santun di rumah, pergaulan bebas, sering berkata kasar, suka merintah, dan lain-lain.

Upaya guru dalam meningkatkan sikap sopan santun pada siswa-siswi kelas VIII F saat diskusi berlangsung dengan menjadikan teladan siswa melalui cara berpakaian yang rapi jadi saat diskusi karena penampilan juga dapat jadi sorotan, bertuturkata yang sopan dan pantas, memberi motivasi pada siswa. Sikap dan perilaku yang ditampilkan harus dapat dicontoh oleh siswa atau dapat dijadikan teladan oleh siswa.

C. Analisis upaya guru dalam meningkatkan sikap kerjasama siswa melalui metode diskusi pada pelajaran IPS kelas VIII F di SMP Negeri 1 Balong Ponorogo?

Salah satu kecakapan hidup yang harus dikuasai oleh siswa yaitu kerja sama, bekerja secara bersama untuk mencapai tujuan bersama dalam suatu tim. Keterampilan kerja sama harus diberikan kepada siswa, karena dapat bermanfaat bagi mereka untuk meningkatkan kerja kelompok dan menentukan keberhasilan hubungan sosial di masyarakat. Kerjasama juga merupakan perilaku saling mendekati guna mengurus kepentingan bersama juga tujuan bersama, kerjasama dapat menumbuhkan rasa kebersamaan, melatih agar terbiasa berkomunikasi, memacu untuk lebih berani mengemukakan pendapat. Dengan menggunakan metode diskusi pembelajaran Ilmu Pengetahuan Sosial menuntut siswa untuk mampu bekerjasama dengan siswa lain. Materi yang dibahas didalam pelajaran IPS sangat mendukung untuk dijadikan bahan diskusi.

Kerjasama juga merupakan bentuk interaksi sosial. Menurut Abdulsyani, kerjasama adalah suatu bentuk proses sosial, dalamnya terdapat aktivitas tertentu yang ditunjukkan untuk mencapai tujuan bersama dengan saling membantu dan saling memahami aktivitas masing-masing. ${ }^{15}$ Kerjasama

15 Abdulsyani, Sosiologi Skematika, Teori, dan Terapan, (Jakarta: Bumi Aksara, 1994) 156. 


\section{Upaya Guru Meningkatkan Sikap Sosial Siswa Melalui Metode Diskusi Pada Mata Pelajaran IPS}

diartikan sebagai kegiatan yang dilakukan secara bersama-sama dari berbagai pihak untuk mencapai tujuan bersama. ${ }^{16}$

Menurut guru IPS kelas VIII F Ibu Siti Nurhayati mengartikan kerjasama merupakan bagian dari kehidupan sosial yang dilakukan oleh sekelompok manusia untuk mencapai tujuan bersama. Masalah yang biasa terjadi jika diadakan kerjasama diskusi kelompok. Masalah sosial ditemukan adanya beberapa siswa yang membentuk geng, selain itu siswa juga ada yang tidak mempunyai kepedulian terhadap orang lain. Rendahnya kemampuan bersosialisasi yang dialami siswa ditunjukkan dari perilaku siswa. Siswa sering mengejek teman lain, siswa sering berdebat ketika berselisih pendapat sehingga menjadikan kelas menjadi gaduh, komunikasi antar siswa kurang baik, dari situlah dapat dilihat bahwasanya murid tidak bisa diajak untuk bekjasama.

Alasan diadakan kegiatan kerjasama, dengan adanya kegiatan diskusi siswa diharapkan dapat meningkatkan kegiatan kerja sama. Siswa yang sebelumnya kurang aktif menjadi aktif mengikuti KBM. Faktor faktor pendukung dan penghambat kegiatan kerjasama saat diskusi berlangsung. Faktor pendukungnya yang ditunjukkan siswa saat kerjasama berdiskusi yaitu, suasana kelas lebih hidup sebab siswa menyerahkan pikiran kepada masalah yang sedang didiskusikan, dapat menaikkan prestasi kepribadian individu seperti sikap demokrasi, toleransi, berpikir kritis, sabar dan sebagainya. Faktor penghambatnya saat kerjasama dengan membentuk kelompok diskusi yaitu, siswa masih memilih-milih, ada sebagian siswa yang kurang berpartisipasi secara aktif dalam diskusi.

Sikap siswa saat mengikuti kegiatan kerjasama, siswa yang sikapnya acuh tak acuh dan tidak bertanggung jawab terhadap hasil diskusi, ada beberapa murid yang mengikuti kegiatan kerjasama saat berdiskusi ada juga yang murid bersikap cuek tidak mau memperhatikan. Cara meningkatkan sikap kerjasama pada siswa kelas VIII F, Selalu memantau siswa mana yang kurang aktif dan jika ada, dibimbing, diarahkan, sampai siswa tersebut paham akan materi yang sedang didiskusikan. Menurut siswanya setelah

\footnotetext{
${ }^{16}$ W.J.S Purwadarmita, Kamus Umum Bahasa Indonesia, (Jakarta: Balai Pustaka, 1985)
} 492. 
menggunakan diskusi, karena dengan adanya kerjasama saat berdiskusi kita dapat bertukar pikiran satu sama lain dan dapat menghidupkan suasana kelas.

\section{PENUTUP}

Jujur merupakan modal dasar dalam kehidupan bersama dan kunci keberhasilan. Melalui kejujuran kita dapat mempelajari, memahami, dan mengerti tentang keseimbangan-keharmonisan. Setelah peneliti melakukan wawancara dengan salah satu guru IPS kelas VIII F, menyampaikan bahwa selalu mengajarkan siswa-siswinya untuk selalu bersikap jujur. Berbagai masalah yang dihadapi oleh siswa-siswi di kelas VIII F mengenai sikap jujurnya dengan ini guru berupaya untuk meningkatkan sikap jujur pada murid.

Sikap sopan santun siswa saat di kelas VIII F saat pembelajaran diskusi kelompok yaitu selama kegiatan diskusi berlangsung, ada siswa yang kurang memperhatikan, saat menyampaikan pendapat kurang sopan dengan bahasa yang baik, kurang menghargai satu sama lain. Akan tetapi juga ada beberapa siswasiswi yang mengikuti kegiatan diskusi dengan baik, menghargai pendapat teman, tidak berbuat gaduh, selalu berbicara dengan baik. Cara menyikapi murid yang kurang sopan santun yaitu dengan menasehati, dan memberi contoh yang baik.

Sikap siswa saat mengikuti kegiatan kerjasama, siswa yang sikapnya acuh tak acuh dan tidak bertanggung jawab terhadap hasil diskusi, ada beberapa murid yang mengikuti kegiatan kerjasama saat berdiskusi ada juga yang murid bersikap cuek tidak mau memperhatikan. Cara meningkatkan sikap kerjasama pada siswa kelas VIII F, Selalu memantau siswa mana yang kurang aktif dan jika ada, dibimbing, diarahkan, sampai siswa tersebut paham akan materi yang sedang didiskusikan.

\section{DAFTAR PUSTAKA}

Abdulsyani. (1994). Sosiologi Skematika, Teori, dan Terapan (p. 156). Jakarta: Bumi Aksara.

Abdul Kadir. (2012). Dasar-Dasar Pendidikan (p. 102). Jakarta: Kencana Prenada Media Group.

Andi Prastowo. (2014). Metode Penelitian Kualitatif Dalam Prespektif Rancangan Penelitian (p. 241). Yogyakarta: AR-Ruzz Media. 
Ariesto Hadi Sutopo dan Andrianus Arif. (2010). Terampil Mengolah Data Kualitatif Dengan NVIVO (p. 11). Jakarta: Kencana Pranada Media Group.

Basrowi dan Suwandi. (2008). Memahami Penelitian Kualitataif (p. 94). Jakarta: PT Rineka Cipta.

Daviq Chairilsyah. (2016). Metode dan Teknik Mengajarkan Kejujuran pada Anak Sejak Usia Dini (p. 9). Riau: Educhild.

Danim Sudarwan. (2004). Perilaku Manusia (p. 97). Jakarta: Perpusnas.

Edy Suharman. (2017). Peran Guru IPS sebagai Pendidik dan Pengajar dalam Meningkatkan Sikap Sosial dan Tanggung Jawab Sosial Siswa SMP (p. 3). Harmoni Sosial: Jurnal Pendidikan IPS.

Emir. (2011). Metodologi Penelitian Kualitatif Analisis Data (p. 129). Jakarta:

Rajawali Press. Mahasiswi Tadris Ilmu Pengetahuan Sosial

Milles dan Huberman.(1992). Analisis Data Kualitatif (p. 16). Jakarta: Universitas Indonesia Press.

Permendikbud Nomor 21 Tahun. (2016) Tentang Stadar Kompetensi Lulusan Pendidikan Dasar dan Menengah.

Sugiyono. (2007). Metodologi Penelitian Kualitatif dan R\&D (p. 341). Bandung: Alfabeta.

Trianto. (2009). Medesain Model Pembelajaran Inovatif-Progresif (p. 121-122). Jakarta: Kencana Prenada Media Group.

W.J.S Purwadarmita. (1985). Kamus Umum Bahasa Indonesia (p. 492). Jakarta: Balai Pustaka. 